\title{
Human polyomavirus infection: Cytological and molecular diagnosis
}

\author{
Patricia Giola de Assis ${ }^{1 *}$, Maria da Glória da Costa Carvalho ${ }^{1}$ \\ ${ }^{1}$ Faculdade de Medicina da Universidade Federal do Rio de Janeiro (FM-UFRJ), Rio de Janeiro, RJ, Brazil
}

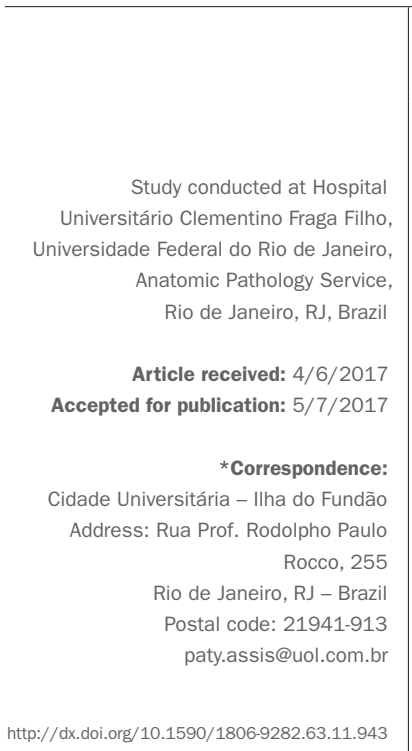

\section{SUMmarY}

Few studies directly compare urinary cytology with molecular methods for detecting BK and JC polyomaviruses. Reactivation of BKV infection is the main risk factor for the development of nephropathy in immunocompromised individuals. The limitation of the cytological method can be attributed to the stage where the infected cell does not have specific and sufficient morphological characteristics for a conclusive diagnosis and can be easily interpreted as degenerative alteration. Moreover, morphologically, it is not possible to differentiate the two types of viruses. Polymerase chain reaction (PCR), not only is a sensitive method, but also allows differentiation of viral types without quantification, and therefore is not indicative of nephropathy. According to the American Society of Nephrology, real-time PCR would be the gold standard to indicate nephropathy because it allows quantifying the number of viral copies.

Keywords: polyomavirus, BK virus, JC virus, kidney transplantation.

\section{INTRODUCTION}

In the 1950s, cytotechnologist Andrew Ricci observed cells with large, homogeneous nuclei in the urinary sediment, mimicking neoplastic cells but not associated with urothelial neoplasia, and called them decoy cells. ${ }^{1}$ The so-called decoy cells have been erroneously diagnosed as cancer cells in the past. It was only in 1968 that it was speculated that these cells could be related to some type of virus, identified as polyomavirus in $1971 .^{2}$

It is believed that they originate in the urothelium of healthy and asymptomatic patients. This hypothesis is based on the fact that it is in the urothelium that the BK virus (BKV) is often latent. Replication of the polyomavirus occurs mainly in the superficial layer of the transitional epithelium, that is, in the umbrella cells that shed easily without causing symptoms or altered renal function. Infected cells are not seen in the kidneys of immunocompetent patients whereas, in immunocompromised patients, nephropathy is characterized by intra-renal replication of BKV with consequent renal dysfunction. The morphological changes caused by viral replication in renal tubular epithelial cells are similar to those observed in transitional cells. Therefore, in BKV nephropathy, decoy cells also originate, probably in the renal parenchyma. ${ }^{3-5}$ It is speculated that BKV nephropathy is caused by an ascending transmission pathway with dissemination of the poly- omavirus originating from the transitional cells to the collecting ducts and proximal tubular epithelial cells in patients with some immunodepression condition. ${ }^{6}$

\section{Diagnosis}

Few studies directly compare urinary cytology with molecular methods for detecting polyomaviruses.

Decoy cells can be easily detected on Papanicolaou stained cytology smears, and its negative predictive value (NPV) is close to $100 \%$. Conversely, the positive predictive value (PPV) of the decoy cell analysis to predict BKV nephropathy (BKVN) ranges from only 25 to $30 \%{ }^{7}$ The persistence of decoy cells in repeated urine samples identifies patients with potential risk for BKVN. On the other hand, according to the "patient screening algorithm and monitoring protocols," a patient with a monolayer-treated urine cytology with more than ten decoy cells is indicated for renal biopsy, with no need for confirmation by PCR. ${ }^{8}$ Although it is relatively easy to detect the presence of decoy cells in urine, it is not possible to distinguish between BKV and JCV.

\section{Classification of decoy cells 6}

- Type 1. The most common are the classic forms characterized by large, homogeneous and amorphous inclusions, with a ground-glass appearance, and a peripheral halo of condensed chromatin. 
- Type 2. They are granular intranuclear inclusions surrounded by a clear halo, so they are called cytomegalovirus-like inclusions.

- Type 3. These are multinucleated decoy cells with granular chromatin.

- Type 4. When infected cells exhibit vesicular nuclei, often with clumped chromatin and evident nucleoli. This is what Koss called the post-inclusion (empty) stage.

The main differential diagnosis of polyomavirus infection in urine is urothelial neoplasms, mainly types 3 and 4. Unfortunately, viral infection can occur in patients with urothelial neoplasia, especially if they are using cytotoxic drugs and infected and neoplastic cells are mixed in the smear. Some details can be analyzed in this differentiation, but, in practice, this is not always possible: decoy cells are seen alone, whereas neoplastic cells can form groups with overlapping nuclei; the nuclei of decoy cells are rounded, in contrast to those of tumor cells, which have irregular nuclei. And if the two conditions (cancer and polyomavirus infection) are associated it may be even more complicated to distinguish one from the other. The search for decoy cells in urine is a marker with a positive predictive value of about $27 \%$, which requires confirmation with more specific techniques, such as polymerase chain reaction. ${ }^{9,10}$

\section{Polymerase chain Reaction}

As the gold standard for the detection and identification of BK and JC viruses, since it can differentiate them by analyzing the generated DNA fragments, ${ }^{9,11,12}$ it revealed the prevalence of BK and JC viruses in the urine of immunocompromised and immunocompetent patients through the technique of polymerase chain reaction (PCR). Even immunocompetent patients excreted BK and JC viruses in the urine, showing that the final diagnosis always depends on a combination of laboratory and clinical data.

\section{Clinical significance of polyomavirus infection}

Humans are the natural hosts of two major members of the Polyomaviridae family that are able to develop persistent subclinical infection in the kidneys and peripheral blood. BKV was isolated from the urine of a patient 4 months after renal transplantation. JCV was isolated from the brain of a patient with Hodgkin's disease with progressive multifocal leukoencephalopathy (PML). Both viruses are excreted in the urine of infected patients, suggesting that the kidney is infected in early stages of contact with this pathogen. In the case of JCV, lymphoid tissues and bone marrow also appear to be involved as early or latent infection sites. ${ }^{13}$
Depending on the degree of reactivity, i.e. the intensity of viral replication, the virus can be eliminated in urine without entering the bloodstream, persist in the urine, or progress to viremia.

It is estimated that more than $70 \%$ of the general population has been exposed to BKV, showing serological evidence of such contact. Asymptomatic reactivation and a low level of replication are observed in 5\% of the healthy population. Reactivation with clinical manifestations is rare in immunocompetent individuals, even though asymptomatic intermittent replication with elimination through urine may occur. Thus, symptoms develop more commonly in immunocompromised individuals, transplant recipients, HIV-infected patients, pregnant women and patients with neoplasms undergoing chemotherapy. BKV is the agent that causes nephropathy in 1-10\% of kidney transplant recipients, which can result in graft loss in about $45 \%$ of cases. There is a correlation between the degree of immunosuppression performed in renal transplant patients and the reactivation of $\mathrm{BKV}$ infection, which is the main risk factor for the development of polyomavirus nephropathy.

\section{Conclusion}

The limitation of the cytological method can be attributed to the stage at which the infected cell does not have specific and sufficient morphological characteristics for a conclusive diagnosis and can be easily interpreted as a degenerative alteration. In 2007 Domingues et al. ${ }^{14}$ described a semi-nested PCR technique capable of differentiating BK and JC viruses from stored clinical samples. However, this method did not allow quantification of viral particles. Real-time PCR has revolutionized the process of quantification of DNA fragments. According to the American Society of Nephrology (2006), this technique would be the gold standard to indicate nephropathy whenever the number of $\mathrm{BKV}$ copies is greater than or equal to 104 .

\section{Resumo}

Infecção pelo poliomavírus humano: diagnóstico citológico e molecular

Poucos estudos comparam diretamente a citologia urinária com métodos moleculares para detecção de poliomavírus BK e JC. A reativação da infecção por BKV é o principal fator de risco para o desenvolvimento de nefropatia em indivíduos imunocomprometidos. A limitação do método citológico pode ser atribuída ao estágio em que a célula infectada não possui características morfológicas específicas e suficientes para um diagnóstico con- 
clusivo, podendo ser facilmente interpretada como alteração degenerativa. Além do mais, morfologicamente, não é possível diferenciar os dois tipos virais. A reação em cadeia pela polimerase (PCR), além de ser um método sensível, permite diferenciar os tipos virais sem quantificá-los, não sendo, portanto, indicativa de nefropatia. Segundo a American Society of Nephrology, a PCR em tempo real seria o padrão-ouro para indicar nefropatia, pois permite quantificar o número de cópias virais.

Palavras-chave: poliomavírus, vírus BK, vírus JC, transplante de rim.

\section{References}

1. Koss LG, Melamed MR. Koss' diagnostic cytology and its histopathologic bases. 5. ed. Philadelphia: Lippincott Williams \& Wilkins; 2006. 1752 p.

2. Gardner SD, Field AM, Coleman DV, Hulme B. New human papovavirus (B.K.) isolated from urine after renal transplantation. Lancet. 1971; 1(7712):1253-7.

3. Nickeleit V, Hirsch HH, Binet IF, Gudat F, Prince O, Dalquen P, et al. Polyomavirus infection of renal allograft recipients: from latent infection to manifest disease. J Am Soc Nephrol. 1999; 10(5):1080-9.

4. Nickeleit, V, Klimkait T, Binet IF, Dalquen P, Del Zenero V, Thiel G, et al. Testing for polyomavirus type BK DNA in plasma to identify renal-allograft recipients with virus nephropathy. N Engl J Med. 2000; 342(18):1309-15.
5. Nickeleit V, Steiger J, Mihatsch MJ. BK virus infection after kidney transplantation. Graft. 2002; 5(Dec Suppl):S46-57.

6. Singh HK, Bubendorf L, Mihatsch MJ, Drachenberg C, Nickeleit V. Urine cytology findings of polyomavirus infections. In: Ahsan $\mathrm{N}$, editor. Polyomaviruses and human diseases. Advances in experimental Medicine and Biology. New York: Springer; 2006. p. 201-12.

7. Varella RB, Almeida JR, Lopes PF, Matos JPS, Menezes P, Lugon JR. BK polyomavirus in kidney transplant recipients: screening, monitoring and clinical management. J Bras Nefrol. 2014; 36(4):529-34.

8. Merlino C, Bergallo M, Gribaudo G, Gregori G, Paolo Segoloni G, Giacchino $\mathrm{F}$, et al. Polyomavirus BK DNA quantification assay to evaluate viral load in renal transplant recipients. J Clin Virol. 2003; 28(3):265-74.

9. Behzad-Behbahani A, Klapper PE, Vallely PJ, Cleator GM, Khoo SH. Detection of BK virus and JC virus DNA in urine samples from immunocompromised (HIV-infected) and immunocompetent (HIV-non-infected) patients using polymerase chain reaction and microplate hybridisation. J Clin Virol. 2004; 29(4):224-9.

10. Fogazzi GB, Cantú M, Saglimbeni L. 'Decoy cells' in the urine due to polyomavirus BK infection: easily seen by phase-contrast microscopy. Nephrol Dial Transplant. 2001; 16(7):1496-8.

11. Randhawa PS, Demetris AJ. Nephropathy due to polyomavirus type BK. N Engl J Med. 2000; 342(18):1361-3.

12. Whiley DM, Mackay IM, Sloots TP. Detection and differentiation of human polyomaviruses JC and BK by LightCycler PCR. J Clin Microbiol. 2001; 39(12):4357-61.

13. Murray PR, Baron EJ, Pfaller MA, Tenover FC, Yolken RH. Manual of clinical microbiology. 7. ed. Washington: American Society for Microbiology; 1999.

14. Domingues JT, Paris F, Schmitt VM. Proposta de reação em cadeia da polimerase (PCR) semi-nested para pesquisa e diferenciação dos vírus BKe JC. Scientia Medica. 2007; 17(2):72-8. 